\title{
Water Quality as a Food Safety Special Issue on Cruise Ships: Applied to Cruises in the Governorates of Luxor and Aswan
}

Maisa Fathey Abd El-latief*

Higher Institute for Tourism and Hotels, Luxor (EGOTH), Egypt

\section{ARTICLE INFO}

Keywords:

Cruise passengers

Safety

Water quality

Microbiologically

Chemically

Health

Fresh water.

\begin{abstract}
Cruises in Egypt have a distinguished international reputation and even in the critical times that Egyptian tourism suffered, these cruises were on the River Nile filled up with tourists coming to them from every part of the world. However, cruise customers can be exposed to dangerous situations involving water borne illnesses. The objectives of the study are to reveal the current water quality situation, investigate the interaction of activities and water quality, and their effects on food safety and human health. The results got fresh water for ships in one of two ways: by producing it onboard by mean (4.58) or by acquiring it from local sources in ports by mean (4.71). The research results were obtained through the questionnaires distribution, as well as obtaining a water sample and analyzing it both microbiologically and chemically. The results of this study showed that the extent of water hygiene and safety in floating hotels in Luxor and Aswan governorates, and the impact of using that water on the health of the inmates, and sources of pollution. (131) questionnaires were distributed to floating hotel managers, while (86) questionnaires were retrieved by $(65.6 \%)$. To measure the extent of awareness and attention to water quality in floating hotels in the governorates of Luxor and Aswan and highlight the sources of pollution in order to pay attention to the health and safety of inmates and workers. A random water sample was obtained from a cruise to ensure the health and safety of water that used on a board of cruises. It has already been proven that there are no microbes, and the report has already confirmed that the water sample is suitable for human consumption. While, the bacteriological analysis of water was done by a medical analysis laboratory, expert in microbiologically and chemically analysis.
\end{abstract}

C2020 Faculty of Tourism and Hotels, Fayoum University All rights reserved

\section{Introduction}

Nile cruises from Luxor to Aswan provide guests to Egypt with an unexampled means of residing and exploring many of Egypt's most cherished olden relics located along the shores of the Nile between Luxor and Aswan (ETP, 2019). On the world's superlative cruise, typically sail from Luxor to Aswan and back, stopping off for tourism (Wendy, 2019). The arrangement of water supply to and on cruises differs frequently from

\footnotetext{
${ }^{*}$ Contact Maisa Fathey Abd El-latief at: mf111@fayoum.edu.eg
} 
that of water supply on ground (Han et al., 2007). Risks of contamination can appear from source water or during storage or distribution on the cruise (World Health Organization (WHO), 2009). Water hygiene and food safety are inextricably mutual. water, like food, is a possibility vehicle for the immediate transmission of operators of sickness and continues to cause significant outbreaks of disease in sophisticated and developing countries (World Health Organization (WHO), 2011). Water is, therefore, also capable of introducing contamination into food and beverage if appropriate care is not taken (Hamed et al., 2013).

Every attempt should be made to achieve drinkingwater that is as secure as practicable. In many respects it is easier to arrange an exporter of hygienic drinking water than to follow strictly the recommendations offered concerning healthy food (Schlaich et al., 2009). Disease is contracted to guests by consuming contaminated food or water. The hazard depends on an assortment of factors. Antithesis to popular belief, food poses a much uttermost hazard to the guest than water (Bartram et al., 2009). The purpose for this is that contamination of water by an organization is prone to a lowering effect, so that insufficient organisms are exposed by an individual at any one time to cause an infection (Toufeek, 2011). Contamination can appear in raw water or as an effect of improper storage or pick-up of contaminants from distribution systems (Ufermann et al., 2011). It can also be contaminated with a wide range of chemicals, both normal and anthropogenic, which are of concern some circumstances depending on the concentrations present (Mouchtouri et al., 2012). In addition, the increasing pressure to optimize water use within cruises may result in the potential for contaminated water to reach food (Du Plessis et al., 2015).

There is the dilemma that water can present some risks to food safety, but it is an essential part of food manufacture and processing (Murray and Taylor, 2015). It is, therefore, vital to minimize the risks and eschew unnecessary damage by ensuring that the needful control measures are put in place. Recently, an approach for quality assurance programs for drinking water supplies has emerged. This has included, for example, approaches based on the generic International Organization for Standardization (ISO) 9001 Quality Standard (Wendy, 2019).

Taylor (2008) proposed the alteration and prevalent application of the Hazard Analysis and Critical Control Point (HACCP) basics, which were officially codified by The National consultative. Committee on microbiological criteria for foods, to drinking water supply safety (Brida and Zapata, 2010). The necessity is to identify the hazard at each phase of the process to assess the risks and to ensure that significantly risks are relieve by prophylactic actions that include arrangement for emergencies (Arvanitoyannis et al., 2010). An inclusive approach to water safety on cruises is essential. This may be achieved by the adoption of water safety plans that cover design, construction, operation, and routine inspection and maintenance (Aijuka and Buys, 2013). Cruises have integral water reservoir and congregation distribution systems. water is also utilized in swimming pools. Safe food, water and sanitation on receptacles are crucial to the health of guests and crew and to the shipping capability to attract and retain competent staff and guests (Murray and Taylor, 2015).

However, guests can be exposed to unhealthy situations involving food and water borne illnesses, negligence and medical mistakes cases of gastroenteritis and colitis of unspecified origin or stomach flu (Taylor, 2008). In addition, cruises' operators have the commitment to protect all guests from injuries contain from maintenance deficiency on board the cruises (Ufermann et al., 2011). If one become ill or is injured while aboard a cruise or land excursion, the cruise operators must provide a sensible standard of care (Amenta et al., 2011).

This study is important because it sheds light on the water pollution in cruises; it provides advice and instruction to prevent the risk of using contaminated water on board cruises in the Nile River. This study attempted also to link different types of water pollution and the incidence of inmates with number of diseases; it gives a strong indication of the views that elucidated the reason behind the use of polluted drinking water source in cruises. It is also a study for decision-makers to address such risks before any losses occur. In addition, this research is important because it sheds light on the causes of water pollution in cruises and their health disadvantages in an attempt to prove this relationship and to clarify these risks to specialists.

\section{Objectives}

The objectives of the study are to reveal the current water quality situation, investigate the interaction of activities and water quality, and their effects on food safety and human health. The purpose of this paper is to review documented outbreaks of quality of water and pollution that associated with floating hotels to identify contributing factors so that: 
1- To develop water safety plan, challenges, and perspectives to success for cruises.

2- To recognize the effectiveness of water quality, identify the sources and causes of water pollution and illuminate them to avoid pollution of all types to preserve the safety of guests and staffs in floating hotels in the governorates of Luxor and Aswan.

3- To try to clarify water problems and awareness to maintain water quality and reach the highest quality in floating hotels.

4- To identify the most polluted areas and identification of hazards on board floating hotels.

5- To determination of control assessment and development of an improvement plan for the practices and improper storage of water on board of floating hotels.

\section{Literature Review}

The Chamber of Tourism Companies head in Upper Egypt clarified that occupancy rates currently in cruises operating between Luxor and Aswan are about $70 \%$, while occupancy rates in fixed hotels are about $50 \%$, indicating that this percentage is currently considered appropriate due to the absence of a vacation and the stopping of flights coming from China with the apparent decline in the number of tourists from Southeast Asia (EMT, 2020).

Improperly managed water is a founded route for infectious disease transmission on cruises (Zhou et al., 2009). New food and water hygiene issues improve as the environment changes. New issues associated with food safety that have emerged support the necessity for continued research (Gaber et al., 2013). To protect the health of guests and crew, water used for potable purposes on cruise should be provided with sanitary safeguards in a multiple-barrier system in order to prevent contamination or pollution during cruise operation (Murray and Taylor, 2015). An adequate and safe water supply is needed for drinking, washing vegetables and fruits, preparing food and beverage, purgation utensils and personal hygiene. Activities that occur in your community can ultimately impact water hygiene and food safety (Du Plessis et al., 2015). Potable water is used in assorted ways on cruises, that including direct human consumption, food preparation and sanitation activities (Miller et al., 2009). Potential uses include preparation of hot and cold beverages, such as coffee, tea and powdered beverages, ice cubes in drinks, reconstitution of dehydrated foods such as soups, noodles and infant formula, food washing and making ready, direct ingestion from cold water taps and water fountains, reconstitution, and ingestion of curative, brushing of teeth, hand and face washing, showering and cleaning of utensils (Liang et al., 2012).

\subsection{Risks Associated with Water Obtained from an Unsafe Source}

Potable water for cruises needs to be obtained only from water supplies that provide potable water of a quality in line with standards recommended in national standards, specifically in relation to microbial, chemical, physical and radiological requirements (Brotherton et al., 2003). The cruise's operator must seek assurance as to the quality of the source water before bunkering (Allam, 2007). The first strategy for prevention of waterborne disease should be to load cruises with water that conforms to the World Health Organization (WHO) guidelines for drinking water quality, whichever are stricter (WHO, 2009). Source water is monitored at the port to ensure that water quality is good and safe. Water quality of water can have profound effectiveness on the microbiological integrity of food (Soller et al., 2010). It shall also be managed in a hygienic technique to prevent any expected or man-made contamination. Some of the causal hazardous agents associated with waterborne disease outbreaks on cruises (WHO, 2011).

\subsection{Risks Associated with Loading and Transfer to Cruises}

It is important that staffs are trained in and understand suitable water handling procedures for disinfecting water (WHO, 2009). Particular attention should be paid to flushing the hoses, disinfecting the loading points, and keeping the hoses hygienic and capped. They should be handled with care to preclude contamination (ISO, 2007). Transfer and delivery system, which includes hydrants, hoses, water boats and water barges; this water transfer process provides various opportunities for the introduction of contaminants into the drinking water (Miller et al., 2009). Transfer of the water from the source to the filling operation shall be conducted in a hygienic style to prevent any contamination (Arvanitoyannis et al., 2010). The system should be designed so that it does not contaminate the water intended for filling, can be effectively sanitized, allows for easy access and inspection of the pipeline should any problems arise (Andriotis and Agiomirgianakis, 2010). Cruises should have plumbing suitable to protect water safety (Hamed et al., 2013). Before being supplied, new cruises should be inspected for compliance with the propose specifications by the relevant competent authority or other authorized independent body. 
Technical standards such as ISO standards should be considered (Du Plessis et al., 2015).

\subsection{Risks Associated with Storage of Water on Cruises}

Storage tanks should be sited higher than the inner independent of the hull and not adjacent to tanks containing oil (Grenfell et al., 2008). They should be sited and be of such dimensions that they are accessible to facilitate examination and hygienic (ISO, 2006). Tanks should be clearly marked "Hygienic water". Storage should never be less than a two-day supply (Mouchtouri et al., 2012). Water storage shall be conducted hygienically to protect against contamination (Aijuka and Buys, 2013). Water shouldn't be retained excessively in water holding tanks. Storage tank should be protected from environmental contamination (Ibrahim, 2013). Maximum storage time should be optimized to minimize pollution hazard and obviate stagnant water (Gaber et al., 2013). Hygienic water tanks must be constructed of metal or other appropriate material that is safe for contact with hygienic water and must be robust enough to exclude contamination (Du Plessis et al., 2015).

\subsection{Risks Associated with Repair and Maintenance}

Regular maintenance is important to ensure that water quality is not compromised (Bartram et al., 2009). However, if repairs are not carried out correctly, they can pose their own threats (Mouchtouri et al., 2012). Cruise rehabilitators should have documented procedures in place for physical hygienic and disinfection before commissioning cruises as well as for dry dock repair (Aijuka and Buys, 2013). All elements of the hygienic water production, treatment and transmission system. In addition, it should be inspected and cleaned, according to the manufacturer's instructions and the planned maintenance system (Du Plessis et al., 2015). The water abstraction should be properly managed and maintained, and safe or disinfected to protect all components from hazard of microbiological, chemical and physical pollution (Murray and Taylor, 2015).

\subsection{Risks Associated with Insufficient Residual Disinfection}

Disinfection is very importance in the supply of safe water. Residual disinfection should not be relied on to treat unhygienic water (Wang, et al., 2009). It is usual to add a disinfectant residual to maintain the quality of the water in the distribution system and to kill pathogens (Ufermann, et al., 2011). The annihilation of pathogenic bacteria is essential involves the use of reactive chemical agents such as chlorine (Mouchtouri, et al., 2012). Disinfection is an effective barrier to many pathogens especially bacteria during water administration (Aijuka and Buys, 2013). Chemical disinfection of a water supply that is contaminated will reduce the overall hazard of disease but may not render the supply safe (Du Plessis, et al., 2015).

\section{Methodology}

Hazards and hazardous events were identified, and risk assessment was conducted of the cruises' water system. Site visits were conducted; findings and observations were recorded and discussed with key crew members were interviewed through a questionnaire form.

The study area is located in Luxor and Aswan governorates where floating hotels are located.

The research was studied and data were obtained from September 2019 to December 2020.

\subsection{Study Population}

The number of floating hotels according to the numbers and classification of floating hotels according to the latest guide for Egyptian hotels as shown in table 1, 189 five-star floating hotels, 46 four-star floating hotels, 24 three-star floating hotels, 3 two-star floating hotels, and 2 floating hotels under classification. The numbers that were already working as Nile cruises during the study period 131 floating hotels. The head of the Chamber of Companies and Agents of Travel and Tourism in the governorate of Luxor that the rate of occupancy of hotels floating between Luxor and Aswan this year up to $60 \%$ in a precedent is the first in nine years during the winter season 2019/2020.

\subsection{The Study Sample}

The questionnaire was distributed to 131 floating hotels on the category of managers and obtained response from 86. Then, one sample of water was obtained from one of the floating hotels as a random sample in order to ensure the water validity and the water quality that used in the floating hotel which provided to guests, as it was analyzed from the chemical and microbiological, as this was done in a specialized microbiological analysis unit.

\subsection{Questionnaire Pre-Testing}

To increase the reliability and validity of the questionnaire, and to measure its attributes' adequateness, clearness and ease of understanding, the 
English questionnaire is reviewed by some academic scholars.

\subsection{Questionnaire Design}

Questionnaire was evaluated using a five-point likert scale ranging from $1=$ 'Not too frequent' to $5=$ 'Very frequently'. Finally, socio-demographic and general questions such as: Age, education and experience about the floating hotels' general managers, in addition to, general information about the floating hotels. The questionnaire prepared for this study is based on a comprehensive literature review and consistent with the objectives of the study. The questionnaire formulated through divided into six main sections of water quality in cruises, in addition general data on floating hotels and basic data on floating hotel managers: the first section is the floating hotels' water resources. The second section contains 16 questions regarding water management plan on board floating hotels to ensure water quality and provide adequate quantities for consumption. Section three: water treatment. It contains seven questions as it indicates the availability of suitable materials for water purification and provision; and determining its percentage and the suitability of this percentage for human consumption. Fourth section: Water pollutants. This part consists of 19 questions, where it contains the extent to which the necessary precautions are made in order to prevent water pollution on board of the floating hotels and the extent to which preventive strategies are followed from waterborne diseases, Table 1 monitoring and taking all necessary measures to ensure that employees keep the floating hotel free of any source for pollution or infection. The fifth part: water tanks on board the floating hotels and the extent of their maintenance, and to ensure their cleanliness and disinfection on a regular and continuous basis; and this part consists of 10 questions. The sixth part consists of 5 questions about the mineral water used in the floating hotels and to verify its standard specifications and its suitability for human use.

\subsection{Sources and Methods of Data Collection}

The research study was based on field studies where data and information were collected from the Ministry of Tourism in Luxor governorate, in addition to interviews with floating hotel managers. The study also relied on the collection and study of scientific research related to the subject of research, and was adopted in the methods of studying the research on questionnaires to learn and study some aspects. This is in addition to many spatial and scout visits to floating hotels.

\subsection{Data Processing}

The data in the research were processed using SPSS Version 20.0 to interpret the results of the questionnaires. While the microbiological and chemical analysis of water was carried out by a specialized analysis unit

\section{Results and Discussion}

Numbers and Classification of Floating Hotels from the Latest Guide to Egyptian Hotels.

\begin{tabular}{|c|c|c|c|c|c|c|c|}
\hline Category & 5 stars & 4 stars & 3 stars & 2 stars & 1 star & Under classification & Total \\
\hline N. & 189 & 46 & 24 & 3 & 0 & 2 & 264 \\
\hline
\end{tabular}

Table (2) showed a report of bacteriological analysis of a random water sample that obtained from a cruise to ensure the health and safety of water that used on a board of cruises. The bacteriological analysis of water was done by a medical analysis laboratory, expert in microbiological analysis. Among the difficulties that the researcher faced in obtaining the samples research and analyzes were the conditions that the country went through during this period (February 2020)

\subsection{Results of Bacteriological Analysis of Water Sample in Cruises}

The results in table (2) shows that the aspect of this sample was clear according to virtual examination
(Normal result), the sample was colour less (Normal result), while, the sample has no odour (Normal result), voable count at $22{ }^{\circ} \mathrm{c}$ is a growth of a type of bacteria called (saprophytes) but within permissible count (Normal result) and voable count at $37 \mathrm{c}$ was the same result at $22 \mathrm{c}$. The total coliform includes bacteria that were considered to be present specifically in the gut and feces of warm-blooded animals (Zero coliform and normal result). While EJKman tve (Positive) fecal coliform was a test used to make identification of coliform bacteria from warm-blooded animals. If water has been polluted by human or animals stooy it will contain colli-bacilli bacteria (this sample showed zero coliform). MPN was a test used to determine number of bacilli bacteria in a volume of $100 \mathrm{ml}$ 
water. Enterococcus fecalis bacteria were classified as a part of gram (positive bacteria). It inhabits the gastro, intestinal tract of humans and other mammals. In this specimen, there was no growth of enterococcus fecalis bacteria (Normal result). Psedomonas aeruginosa was a gramnegative bacterium that can cause disease in plants and animals or humans. In this specimen of water, there was no growth of pseudomonas aeruginosa bacteria. These results agreed with Ormeci et al. (2005), Grenfell et al. (2008), AWWA (2006), ASSE (2016), APHA (2017), and Manoiu and Craciun (2019).

\section{Table 2}

The Report of Bacteriological Analysis of Water in Cruise.

\begin{tabular}{|c|c|c|}
\hline \multicolumn{3}{|c|}{$\begin{array}{l}\text { Report of Bacteriological Analysis of water in Luxor } \\
- \text { Aswan Cruise }\end{array}$} \\
\hline \multicolumn{3}{|c|}{ Bacteriology } \\
\hline Variables & Results & Normal \\
\hline Aspect & Clear & Clear \\
\hline Colour & Colourless & Colourless \\
\hline Odour & Odourless & Odourless \\
\hline $\begin{array}{l}\text { Voable count } \\
\text { at } 22 \mathrm{c}\end{array}$ & $\begin{array}{l}\text { Growth of } \\
\text { Saproohytes } \\
\text { Within permissible } \\
\text { count }\end{array}$ & $<100 \mathrm{CFU} / \mathrm{ml}$. \\
\hline $\begin{array}{l}\text { Voable count } \\
\text { at } 37 \mathrm{c}\end{array}$ & $\begin{array}{l}\text { Growth of } \\
\text { Saproohytes } \\
\text { Within permissible } \\
\text { count }\end{array}$ & $<100 \mathrm{CFU} / \mathrm{ml}$. \\
\hline $\begin{array}{l}\text { Total } \\
\text { Cloiform } \\
\text { count } \\
\end{array}$ & Zero cloiform & Zero coliform \\
\hline (MPN) & $\begin{array}{l}\text { Bacilli in } 100 \mathrm{ml} \\
\text { water }\end{array}$ & $\begin{array}{l}\text { Bacilli/100 ml } \\
\text { water }\end{array}$ \\
\hline $\begin{array}{l}\text { Ejkman } \\
\text { positive fecal } \\
\text { Coliform. }\end{array}$ & Zero cloiform & Zero cloiform \\
\hline $\begin{array}{l}\text { Count } \\
\text { (MPN). }\end{array}$ & $\begin{array}{l}\text { Bacilli in } 100 \mathrm{ml} \\
\text { water }\end{array}$ & $\begin{array}{l}\text { Bacilli/100 ml } \\
\text { water }\end{array}$ \\
\hline $\begin{array}{l}\text { Enterococcus } \\
\text { fecalis }\end{array}$ & $\begin{array}{l}\text { No growth of } \\
\text { enterococcus } \\
\text { facalis }\end{array}$ & No growth \\
\hline $\begin{array}{l}\text { Psedomonas } \\
\text { aeruginosa }\end{array}$ & $\begin{array}{l}\text { No growth } \\
\text { pseudomonas } \\
\text { Aeruginosa. }\end{array}$ & No growth \\
\hline $\mathrm{Cc}$ & $\begin{array}{l}\text { ater sample is suital } \\
\text { consumption. }\end{array}$ & for human \\
\hline
\end{tabular}

5.2 Results of Water Sample Analysis of Chemical Analysis

Total dissolved solid was a measure of the dissolved content of all (inorganic - organic) substances present in water. Chloride analysis in water sample must be between (1-1000) ppm part $/ \mathrm{m}$ to be normal in fresh water. Chloride was $250 \mathrm{ppm}$ (Normal level). These results agreed with Ormeci et al. (2005), AWWA (2006), ASSE (2016) and Manoiu and Craciun (2019).

\subsection{Results of a Questionnaire}

Among 86 hotels included in the study, $4.6 \%$ were rated as 4 stars hotel and $95.3 \%$ were rated as 5 stars hotels, that showed in table (3). While the number of cruises that was already operating in this period (131) floating hotel due to repairs and the tourists' number of trips that was by $(65.6 \%)$.

Table 3

Description of Hotels included in Study.

\begin{tabular}{|c|c|c|}
\hline Variables & \multicolumn{2}{|c|}{ Number $(\mathrm{n}=86)$} \\
\hline Hotel Rating & 4 & $4.6 \%$ \\
\hline 4 stars' hotels. & 82 & $95.3 \%$ \\
\hline 5 stars' hotels. & 86 & $100 \%$ \\
\hline Total
\end{tabular}

Table 4 illustrated that $(98.8 \%)$ of study group aged above 35 years old with $(87.2 \%)$ of them were university education and $(1.16 \%)$ receive intermediate level of education and $(3.5 \%)$ finish postgraduate education, as regards years of experience $(1.16 \%)$ have experience for 5 to 10 years, $(98.8 \%)$ for more than 10 years.

\section{Table 4}

Description of Demographic Characters among Study Group.

\begin{tabular}{|c|c|c|}
\hline Variables & \multicolumn{2}{|c|}{ Number (n= 86) } \\
\hline Age & 0 & $0 \%$ \\
\hline 25-35 years old & 85 & $98.8 \%$ \\
\hline More than 35 years old & 1 & $1.16 \%$ \\
\hline Missing & 86 & $100 \%$ \\
\hline Total \\
\hline Educational level & 1 & $1.16 \%$ \\
\hline Intermediate level & 81 & $94.18 \%$ \\
\hline University & 3 & $3.5 \%$ \\
\hline Postgraduate & 85 & $98.8 \%$ \\
\hline Total & 1 & $1.16 \%$ \\
\hline Missing & 86 & $100 \%$ \\
\hline Total & 0 & $0 \%$ \\
\hline Years of experience & 1 & $1.16 \%$ \\
\hline Less than 5 years & 83 & $98.8 \%$ \\
\hline 5-10 years & 84 & $97.7 \%$ \\
\hline More than 10 years & 2 & $2.3 \%$ \\
\hline Total & 86 & $100 \%$ \\
\hline Missing
\end{tabular}

\subsection{Internal Use of Water}




\subsubsection{Water Resources}

Table 5 illustrated that as regards internal use of water; $79.5 \%$ and $71.8 \%$ of study group indicated that they obtain frequently water from external sources and stored. They obtain it through Nile water and is analyzed and processed; respectively with mean score above 4 . The results confirmed that the organization of water supply to and on ships differs considerably from that of water supply on ground. These results agreed with Wahab and Badawy (2004). The results also confirmed that Table 5

Internal Use of Water among Study Group.

\begin{tabular}{|c|l|c|c|c|c|c|c|c|}
\hline \multirow{2}{*}{ N. } & \multicolumn{1}{|c|}{ Element } & $\begin{array}{c}\text { Very } \\
\text { frequently }\end{array}$ & Frequently & Not sure & Scarcely & $\begin{array}{c}\text { Not too } \\
\text { frequent }\end{array}$ & Mean & S.D \\
\cline { 3 - 7 } & No. (\%) & No. (\%) & No. (\%) & No. (\%) & No. (\%) & N \\
\hline $\mathbf{2}$ & $\begin{array}{l}\text { Water is obtained from } \\
\text { external sources and stored. }\end{array}$ & $31(79.5 \%)$ & $4(10.3 \%)$ & $0(0 \%)$ & $4(10.3 \%)$ & $0(0 \%)$ & 4.58 & 0.93 \\
\hline 2 & $\begin{array}{l}\text { Water is obtained through } \\
\text { Nile water and is analyzed } \\
\text { and processed. }\end{array}$ & $28(71.8 \%)$ & $11(28.2 \%)$ & $0(0 \%)$ & $0(0 \%)$ & $0(0 \%)$ & 4.71 & 0.45 \\
\hline
\end{tabular}

\subsubsection{Water Consumption and Availability}

Table (6) illustrated that as for water consumption and availability more than $(80 \%)$ of study group mentioned that frequently, and very frequently, There is a water management plan on cruise by $(66.7 \%)$, The quality of water on board is confirmed by specialists by (52.9\%), High-quality water management arrangements are in place to prepare food and beverages, The quantities of water suitable for human use on board are adequately supplied to meet the projected needs for all purposes, Wash dishes and utensils used in cooking and other utensils from the same source, water is provided in swimming pools through drinking water tanks, and water is provided in swimming pools through waste water treatment, with a general mean score above 4 . These results agreed with WHO (2002), Marı'a et al. (2008), risks of contamination can arise from source water at the port or during loading, storage or distribution on the cruise. These results agreed with Han et al. (2007). Where the results confirmed that water hygiene and food safety are inextricably linked. water, like food, is a potential vehicle for the direct transmission of agents of sickness and continues to cause significant outbreaks of disease in developed and developing countries. These results also agreed with Mouchtouri et al. (2012) and World Health Organization (2010).

\section{Table 6}

Water Consumption and Availability among Study Group.

\begin{tabular}{|l|l|l|l|l|l|l|l|l|}
\hline \multirow{2}{*}{ N. } & Element & $\begin{array}{l}\text { Very } \\
\text { frequently }\end{array}$ & Frequently & $\begin{array}{l}\text { Not } \\
\text { sure }\end{array}$ & Scarcely & $\begin{array}{l}\text { Not too } \\
\text { frequent }\end{array}$ & Mean & S.D. \\
\hline 1 & $\begin{array}{l}\text { No. }(\%) \\
\text { management plan on cruise. }\end{array}$ & $\begin{array}{l}26 \\
(66.7 \%)\end{array}$ & $13(33.3 \%)$ & $0(0 \%)$ & $0(0 \%)$ & $0(0 \%)$ & 4.66 & 0.47 \\
\hline 2 & $\begin{array}{l}\text { The quality of water on } \\
\text { board is confirmed by } \\
\text { specialists. }\end{array}$ & $\begin{array}{l}18 \\
(52.9 \%)\end{array}$ & $16(47.1 \%)$ & $0(0 \%)$ & $0(0 \%)$ & $0(0 \%)$ & 4.52 & 0.51 \\
\hline 3 & $\begin{array}{l}\text { High-quality water } \\
\text { management arrangements }\end{array}$ & $\begin{array}{l}25 \\
(64.1 \%)\end{array}$ & $7(17.9 \%)$ & $0(0 \%)$ & $2(5.1 \%)$ & $5(12.8 \%)$ & 4.15 & 1.42 \\
\hline
\end{tabular}


M. F. Abd El-latif/IJHTH vol 14 issue 2 (2020) 12-27

\begin{tabular}{|c|c|c|c|c|c|c|c|c|}
\hline \multirow[t]{2}{*}{$\mathrm{N}$} & \multirow{2}{*}{ Element } & $\begin{array}{l}\text { Very } \\
\text { frequently }\end{array}$ & Frequently & $\begin{array}{l}\text { Not } \\
\text { sure }\end{array}$ & Scarcely & $\begin{array}{l}\text { Not too } \\
\text { frequent }\end{array}$ & \multirow[t]{2}{*}{ Mean } & \multirow[t]{2}{*}{ S.D. } \\
\hline & & No. $(\%)$ & No. $(\%)$ & No. $(\%)$ & No. $(\%)$ & No. $(\%)$ & & \\
\hline & $\begin{array}{l}\text { are in place to prepare food } \\
\text { and beverages. }\end{array}$ & & & & & & & \\
\hline 4 & $\begin{array}{l}\text { Stored water is used for } \\
\text { direct consumption in food } \\
\text { and beverage preparation. }\end{array}$ & $3(7.9 \%)$ & $4(10.5 \%)$ & $0(0 \%)$ & $3(7.9 \%)$ & $28(73.7 \%)$ & 1.71 & 1.35 \\
\hline 5 & $\begin{array}{l}\text { The quantities of water } \\
\text { suitable for human use on } \\
\text { board are adequately } \\
\text { supplied to meet the } \\
\text { projected needs for all } \\
\text { purposes. }\end{array}$ & $\begin{array}{l}29 \\
(74.4 \%)\end{array}$ & $9(23.1 \%)$ & $0(0 \%)$ & $0(0 \%)$ & $0(0 \%)$ & 4.66 & 0.74 \\
\hline 6 & $\begin{array}{l}\text { The water stored on the ship } \\
\text { is used to prepare food and } \\
\text { drinks for guests. }\end{array}$ & $5(12.8 \%)$ & $0(0 \%)$ & $\begin{array}{l}1 \\
(2.6 \%)\end{array}$ & $3(7.7 \%)$ & $\begin{array}{l}30 \\
(76.9 \%)\end{array}$ & 1.64 & 1.37 \\
\hline 7 & $\begin{array}{l}\text { The water stored on board } \\
\text { is used for hygiene } \\
\text { activities. }\end{array}$ & $\begin{array}{l}15 \\
(40.5 \%)\end{array}$ & $13(35.1 \%)$ & $\begin{array}{l}5 \\
(13.5 \%)\end{array}$ & $1(2.7 \%)$ & $3(8.1 \%)$ & 3.97 & 1.18 \\
\hline 8 & $\begin{array}{l}\text { Hot and cold drinks are } \\
\text { prepared such as coffee, tea, } \\
\text { juices and other stored } \\
\text { water. }\end{array}$ & $4(10.3 \%)$ & $1(2.6 \%)$ & $0(0 \%)$ & $1(2.6 \%)$ & $\begin{array}{l}33 \\
(84.6 \%)\end{array}$ & 1.51 & 1.29 \\
\hline 9 & $\begin{array}{l}\text { Ice cubes used in beverages } \\
\text { are manufactured from the } \\
\text { same source. }\end{array}$ & $3(7.7 \%)$ & $1(2.6 \%)$ & $0(0 \%)$ & $1(2.6 \%)$ & $\begin{array}{l}34 \\
(87.2 \%)\end{array}$ & 1.41 & 1.16 \\
\hline 10 & $\begin{array}{l}\text { Wash dishes and utensils } \\
\text { used in cooking and other } \\
\text { utensils from the same } \\
\text { source. }\end{array}$ & $\begin{array}{l}20 \\
(51.3 \%)\end{array}$ & $14(35.9 \%)$ & $0(0 \%)$ & $4(10.3 \%)$ & $1(2.6 \%)$ & 4.23 & 1.06 \\
\hline 11 & $\begin{array}{l}\text { The food is washed and } \\
\text { prepared from the water } \\
\text { stored in the cruise. }\end{array}$ & $\begin{array}{l}11 \\
(28.9 \%)\end{array}$ & $0(0 \%)$ & $0(0 \%)$ & $\begin{array}{l}22 \\
(57.9 \%)\end{array}$ & $5(13.2 \%)$ & 3.89 & 1.22 \\
\hline 12 & $\begin{array}{l}\text { Hand wash and wash from } \\
\text { the stored water in the } \\
\text { cruise. }\end{array}$ & $2(5.1 \%)$ & $6(15.4 \%)$ & $0(0 \%)$ & $6(15.4 \%)$ & $\begin{array}{l}25 \\
(64.1 \%)\end{array}$ & 1.82 & 1.31 \\
\hline 13 & $\begin{array}{l}\text { Lower quality water is used } \\
\text { for laundry purposes. }\end{array}$ & $0(0 \%)$ & $3(7.7 \%)$ & $0(0 \%)$ & $8(20.5 \%)$ & $\begin{array}{l}28 \\
(71.8 \%)\end{array}$ & 1.43 & 0.85 \\
\hline 14 & $\begin{array}{l}\text { Water stored in swimming } \\
\text { pools is used with lower } \\
\text { quality. }\end{array}$ & $2(5.1 \%)$ & $2(5.1 \%)$ & $0(0 \%)$ & $\begin{array}{l}12 \\
(30.8 \%)\end{array}$ & $\begin{array}{l}23 \\
(59.0 \%)\end{array}$ & 1.66 & 1.08 \\
\hline 15 & $\begin{array}{l}\text { Water is provided in } \\
\text { swimming pools through } \\
\text { drinking water tanks. }\end{array}$ & $\begin{array}{l}17 \\
(44.7 \%)\end{array}$ & $14(36.8 \%)$ & $0(0 \%)$ & $3(7.9 \%)$ & $4(10.5 \%)$ & 3.97 & 1.32 \\
\hline 16 & $\begin{array}{l}\text { Water is provided in } \\
\text { swimming pools through } \\
\text { wastewater treatment. }\end{array}$ & $\begin{array}{l}18 \\
(47.4 \%)\end{array}$ & $17(44.7 \%)$ & $0(0 \%)$ & $0(0 \%)$ & $3(7.9 \%)$ & 4.23 & 1.07 \\
\hline
\end{tabular}

\subsubsection{Water Treatment}

Table 7 illustrated that as regards water treatment more than $85 \%$ of study group agreed on that frequently, and very frequently, in hotels a Proper cleaning materials are provided with a mean of 4.78, Pre-used water is used again after treatment in other uses with a mean of 4.38 , The proportion of disinfectants shall be determined to provide the lowest level of safety according to the permissible rates with a mean of 4.51 , The chemicals used in such treatment are subject to safety and safety procedures with a mean of 4.43), Taste and flavor 
are lacking due to processing and may be unappealing to all with a mean of (4.23), water is disinfected and chemicals are added in appropriate quantities in accordance with the required specifications and tolerances with a mean of (4.56), and the processing units are designed to ensure efficient operation with the production of potable water in accordance with international quality with a mean of (4.74). These results agreed with Ormeci et al. (2005), Grenfell et al. (2008), WWA (2006), Zhou et al. (2009), WHO (2009), WHO (2011), ASSE (2016); and APHA (2017).

Table (7)

Water Treatment among Study Group.

\begin{tabular}{|c|c|c|c|c|c|c|c|c|}
\hline \multirow[t]{2}{*}{ N. } & \multirow[t]{2}{*}{ Element } & $\begin{array}{l}\text { Very } \\
\text { frequently }\end{array}$ & Frequently & $\begin{array}{l}\text { Not } \\
\text { sure }\end{array}$ & Scarcely & $\begin{array}{l}\text { Not too } \\
\text { frequent }\end{array}$ & \multirow[t]{2}{*}{ Mean } & \multirow[t]{2}{*}{ S.D } \\
\hline & & No. (\%) & No. (\%) & No. $(\%)$ & No. (\%) & No. $(\%)$ & & \\
\hline 1 & $\begin{array}{l}\text { Proper cleaning materials are } \\
\text { provided. }\end{array}$ & $\begin{array}{l}29 \\
(78.4 \%)\end{array}$ & $8(21.6 \%)$ & $0(0 \%)$ & $0(0 \%)$ & $0(0 \%)$ & 4.78 & 0.42 \\
\hline 2 & $\begin{array}{l}\text { Pre-used water is used again } \\
\text { after treatment in other uses. }\end{array}$ & $\begin{array}{l}27 \\
(69.2 \%)\end{array}$ & $8(20.5 \%)$ & $0(0 \%)$ & $0(0 \%)$ & $4(10.3 \%)$ & 4.38 & 1.22 \\
\hline 3 & $\begin{array}{l}\text { The proportion of } \\
\text { disinfectants shall be } \\
\text { determined to provide the } \\
\text { lowest level of safety } \\
\text { according to the permissible } \\
\text { rates. }\end{array}$ & $\begin{array}{l}26 \\
(66.7 \%)\end{array}$ & $11(28.2 \%)$ & $0(0 \%)$ & $0(0 \%)$ & $2(5.1 \%)$ & 4.51 & 0.94 \\
\hline 4 & $\begin{array}{l}\text { Water is disinfected and } \\
\text { chemicals are added in } \\
\text { appropriate quantities in } \\
\text { accordance with the required } \\
\text { specifications and tolerances. }\end{array}$ & $28(71.8 \%)$ & $9(23.1 \%)$ & $0(0 \%)$ & $0(0 \%)$ & $2(5.1 \%)$ & 4.56 & 0.94 \\
\hline 5 & $\begin{array}{l}\text { Taste and flavor are lacking } \\
\text { due to processing and may be } \\
\text { unappealing to all. }\end{array}$ & $\begin{array}{l}20 \\
(51.3 \%)\end{array}$ & $13(33.3 \%)$ & $\begin{array}{l}2 \\
(5.1 \%)\end{array}$ & $3(7.7 \%)$ & $1(2.6 \%)$ & 4.23 & 1.03 \\
\hline 6 & $\begin{array}{l}\text { The chemicals used in such } \\
\text { treatment are subject to safety } \\
\text { and safety procedures. }\end{array}$ & $\begin{array}{l}29 \\
(74.4 \%)\end{array}$ & $5(12.8 \%)$ & $0(0 \%)$ & $3(7.7 \%)$ & $2(5.1 \%)$ & 4.43 & 1.16 \\
\hline 7 & $\begin{array}{l}\text { The processing units are } \\
\text { designed to ensure efficient } \\
\text { operation with the production } \\
\text { of potable water in } \\
\text { accordance with international } \\
\text { quality. }\end{array}$ & $31(79.5 \%)$ & $6(15.4 \%)$ & $\begin{array}{l}2 \\
(5.1 \%)\end{array}$ & $0(0 \%)$ & $0(0 \%)$ & 4.74 & 0.54 \\
\hline
\end{tabular}

\subsubsection{Water Contaminants}

Table 8 illustrated that as regards water contaminates; more than $85 \%$ of study group agreed on that frequently, and very frequently, in hotels that Chemical and microbiological analyzes are carried out to measure water quality continuously, Ships are provided with water that complies with World Health Organization (WHO) guidelines on the quality of water suitable for human use, Precautions are taken to prevent water contamination with a mean of 4.84, A strategy for the prevention of waterborne diseases is followed with a mean of 4.76 , A periodical follow-up is carried out by specialists to conserve water in various sources in the floating hotel free of sources of pollution and infection with a mean of 4.84, All possible measures shall be taken to ensure that the floating hotel staff keeps the hotel free from pollution and pollution sources with a mean of 4.76 , There is periodic control by the competent authorities of the water used in the cruise and the necessary procedures are taken with a mean of 4.61, Periodic reports on water quality are carried out by specialists, Health protection and medical care are provided on board with a mean of 4.53 , The ship's crew members receive good training in food and water safety and health with a mean of 4.50 , A risk management and maintenance system is available to ensure that health risks are prevented 
on the cruise with a mean of 4.71 , and The administration shall ensure the quality and nature of the source water before supplying the vessel with water; with a general mean score above 4 . These results agreed with Davison et al. (2005), Meyer et al. (2007), Bartram et al. (2009), Mouchtouri et al. (2012); and AWWA (2015).

On the other hand, higher percentage of responders in the study said it is scarcely and not too frequent to presence of pest management and rodents on board the cruise by $35.9 \%$, Some cases of diarrhea, vomiting, fainting, etc. have emerged, as a result of water consumption on the cruise with a mean of 1.66, and There are some cases of diseases caused by toxic chemicals contaminated with water with a mean of 2.48 , with a general mean score around 2 This was proven by the sample obtained, as it proved that the water is free of microbes and is suitable for human consumption and there are no damages that can be caused to humans because of consuming cruises water. These agreed with Health Protection Agency (HPA) (2003), Iolanda et al. (2013); and NSF (2013).

Table 8

Water Contaminants among Study Group.

\begin{tabular}{|c|c|c|c|c|c|c|c|c|}
\hline \multirow[t]{2}{*}{$\mathrm{N}$. } & \multirow[t]{2}{*}{ Element } & \multirow{2}{*}{\begin{tabular}{|l|}
$\begin{array}{l}\text { Very } \\
\text { frequently }\end{array}$ \\
No. $(\%)$ \\
\end{tabular}} & \multirow{2}{*}{$\begin{array}{l}\text { Frequently } \\
\text { No. }(\%) \\
\end{array}$} & \multirow{2}{*}{$\begin{array}{l}\begin{array}{l}\text { Not } \\
\text { sure }\end{array} \\
\text { No. }(\%) \\
\end{array}$} & \multirow{2}{*}{$\begin{array}{l}\text { Scarcely } \\
\text { No. }(\%)\end{array}$} & \multirow{2}{*}{$\begin{array}{l}\begin{array}{l}\text { Not too } \\
\text { frequent }\end{array} \\
\text { No. }(\%) \\
\end{array}$} & \multirow[t]{2}{*}{ Mean } & \multirow[t]{2}{*}{ S.D. } \\
\hline & & & & & & & & \\
\hline 1 & $\begin{array}{l}\text { Precautions are taken to } \\
\text { prevent water contamination. }\end{array}$ & $\begin{array}{l}33 \\
(84.6 \%) \\
\end{array}$ & $6(15.4 \%)$ & $0(0 \%)$ & $0(0 \%)$ & $0(0 \%)$ & 4.84 & 0.36 \\
\hline 2 & $\begin{array}{l}\text { A strategy for the prevention } \\
\text { of waterborne diseases is } \\
\text { followed. }\end{array}$ & $\begin{array}{l}30 \\
(76.9 \%)\end{array}$ & $9(23.1 \%)$ & $0(0 \%)$ & $0(0 \%)$ & $0(0 \%)$ & 4.76 & 0.42 \\
\hline 3 & $\begin{array}{l}\text { Ships are provided with water } \\
\text { that complies with WHO } \\
\text { guidelines on the quality of } \\
\text { water suitable for human use. }\end{array}$ & $\begin{array}{l}26 \\
(66.7 \%)\end{array}$ & $13(33.3 \%)$ & $0(0 \%)$ & $0(0 \%)$ & $0(0 \%)$ & 4.66 & 0.47 \\
\hline 4 & $\begin{array}{l}\text { Chemical and } \\
\text { microbiological analyzes are } \\
\text { carried out to measure water } \\
\text { quality continuously. }\end{array}$ & $\begin{array}{l}25 \\
(64.1 \%)\end{array}$ & $14(35.9 \%)$ & $0(0 \%)$ & $0(0 \%)$ & $0(0 \%)$ & 4.64 & 0.48 \\
\hline 5 & $\begin{array}{l}\text { A periodical follow-up is } \\
\text { carried out by specialists to } \\
\text { conserve water in various } \\
\text { sources in the floating hotel } \\
\text { free of sources of pollution } \\
\text { and infection. }\end{array}$ & $\begin{array}{l}33 \\
(84.6 \%)\end{array}$ & $6(15.4 \%)$ & $0(0 \%)$ & $0(0 \%)$ & $0(0 \%)$ & 4.84 & 0.36 \\
\hline 6 & $\begin{array}{l}\text { All possible measures shall } \\
\text { be taken to ensure that the } \\
\text { floating hotel staff keeps the } \\
\text { hotel free from pollution and } \\
\text { pollution sources. }\end{array}$ & $\begin{array}{l}30 \\
(76.9 \%)\end{array}$ & $9(23.1 \%)$ & $0(0 \%)$ & $0(0 \%)$ & $0(0 \%)$ & 4.76 & 0.42 \\
\hline 7 & $\begin{array}{l}\text { There is periodic control by } \\
\text { the competent authorities of } \\
\text { the water used in the cruise } \\
\text { and the necessary procedures } \\
\text { are taken. }\end{array}$ & $\begin{array}{l}24 \\
(61.5 \%)\end{array}$ & $15(38.5 \%)$ & $0(0 \%)$ & $0(0 \%)$ & $0(0 \%)$ & 4.61 & 0.49 \\
\hline 8 & $\begin{array}{l}\text { Periodic reports on water } \\
\text { quality are carried out by } \\
\text { specialists. }\end{array}$ & $\begin{array}{l}21 \\
(53.8 \%)\end{array}$ & $18(46.2 \%)$ & $0(0 \%)$ & $0(0 \%)$ & $0(0 \%)$ & 4.53 & 0.50 \\
\hline 9 & $\begin{array}{l}\text { Health protection and medical } \\
\text { care are provided on board. }\end{array}$ & $\begin{array}{l}28 \\
(73.7 \%) \\
\end{array}$ & $10(26.3 \%)$ & $0(0 \%)$ & $0(0 \%)$ & $0(0 \%)$ & 4.73 & 0.44 \\
\hline 10 & $\begin{array}{l}\text { There is pest management } \\
\text { and rodents on board the } \\
\text { cruise. }\end{array}$ & $\begin{array}{l}11 \\
(28.2 \%)\end{array}$ & $6(15.4 \%)$ & $0(0 \%)$ & $8(20.5 \%)$ & $\begin{array}{l}14 \\
(35.9 \%)\end{array}$ & 2.79 & 1.71 \\
\hline
\end{tabular}


M. F. Abd El-latif/IJHTH vol 14 issue 2 (2020) 12-27

\begin{tabular}{|c|c|c|c|c|c|c|c|c|}
\hline \multirow[t]{2}{*}{ N. } & \multirow[t]{2}{*}{ Element } & $\begin{array}{l}\text { Very } \\
\text { frequently }\end{array}$ & Frequently & $\begin{array}{l}\text { Not } \\
\text { sure }\end{array}$ & Scarcely & $\begin{array}{l}\text { Not too } \\
\text { frequent }\end{array}$ & \multirow[t]{2}{*}{ Mean } & \multirow[t]{2}{*}{ S.D. } \\
\hline & & No. $(\%)$ & No. $(\%)$ & No. (\%) & No. (\%) & No. $(\%)$ & & \\
\hline 11 & $\begin{array}{l}\text { Some cases of diarrhea, } \\
\text { vomiting, fainting, etc. have } \\
\text { emerged because of water } \\
\text { consumption on the cruise. }\end{array}$ & $0(0 \%)$ & $2(5.1 \%)$ & $0(0 \%)$ & $\begin{array}{l}20 \\
(51.3 \%)\end{array}$ & $\begin{array}{l}17 \\
(43.6 \%)\end{array}$ & 1.66 & 0.73 \\
\hline 12 & $\begin{array}{l}\text { The ship's crew members } \\
\text { receive good training in food } \\
\text { and water safety and health. }\end{array}$ & $\begin{array}{l}27 \\
(71.1 \%)\end{array}$ & $8(21.1 \%)$ & $0(0 \%)$ & $1(2.6 \%)$ & $2(5.3 \%)$ & 4.50 & 1.03 \\
\hline 13 & $\begin{array}{l}\text { A risk management and } \\
\text { maintenance system is } \\
\text { available to ensure that health } \\
\text { risks are prevented on the } \\
\text { cruise. }\end{array}$ & $\begin{array}{l}30 \\
(76.9 \%)\end{array}$ & $8(20.5 \%)$ & $0(0 \%)$ & $1(2.6 \%)$ & $0(0 \%)$ & 4.71 & 0.60 \\
\hline 14 & $\begin{array}{l}\text { There are some cases of } \\
\text { diseases caused by toxic } \\
\text { chemicals contaminated with } \\
\text { water. }\end{array}$ & $7(17.9 \%)$ & $7(17.9 \%)$ & $1(2.6 \%)$ & $7(17.9 \%)$ & $17(43.6 \%)$ & 2.48 & 1.62 \\
\hline 15 & $\begin{array}{l}\text { The administration shall } \\
\text { ensure the quality and nature } \\
\text { of the source water before } \\
\text { supplying the vessel with } \\
\text { water. }\end{array}$ & $26(66.7 \%)$ & $7(17.9 \%)$ & $0(0 \%)$ & $2(5.1 \%)$ & $4(10.3 \%)$ & 4.25 & 1.33 \\
\hline
\end{tabular}

\subsubsection{Water Tanks}

Table (9) illustrated that as regards water tanks; more than $(85 \%)$ of study group agreed on that frequently, and very frequently, in hotels that the Maintenance, cleaning and periodic maintenance of water tanks with a mean of 4.84 , The design of reservoirs is suitable to prevent the mixing of drinking water with other water in the case of multiple types of water on cruise with a mean of (4.66), Reservoirs are located in rooms that preserve them with a mean of (4.58), Drinking water tanks shall be made of metal or other suitable material for the storage of potable water and shall not allow contamination with a mean of (4.33), Regular maintenance of water tanks for anti- corrosive coatings with a mean of 4.23 , The water tanks are equipped with a ventilation outlet designed and designed to prevent the entry of contaminated materials and bacteria and protect it with a well-sealed net that prevents the entry of insects and contaminants with a mean of 4.64 , The tanks are regularly cleaned and cleaned with a mean of 4.69 , and No person with infectious disease is allowed to enter the water tanks with a mean of 4.64, with a general mean score above 4 . These results agreed with Davison et al. (2005), Meyer et al. (2007), Mar1'a et al. (2008), Bartram et al. (2009), NSF (2013), Srećko (2016), APHA (2017) and Manoiu and Craciun (2019).

Table 9

Water Tanks among Study Group.

\begin{tabular}{|c|c|c|c|c|c|c|c|c|}
\hline \multirow{2}{*}{ N. } & \multirow{2}{*}{ Element } & $\begin{array}{l}\text { Very } \\
\text { frequently }\end{array}$ & Frequently & $\begin{array}{l}\text { Not } \\
\text { sure }\end{array}$ & Scarcely & $\begin{array}{l}\text { Not too } \\
\text { frequent }\end{array}$ & \multirow{2}{*}{ Mean } & \multirow{2}{*}{ S.D. } \\
\hline & & No. (\%) & No. (\%) & $\begin{array}{l}\text { No. } \\
(\%)\end{array}$ & No. (\%) & No. $(\%)$ & & \\
\hline 1 & $\begin{array}{l}\text { Maintenance, cleaning, and periodic } \\
\text { maintenance of water tanks. }\end{array}$ & $\begin{array}{l}33 \\
(84.6 \%)\end{array}$ & $6(15.4 \%)$ & $0(0 \%)$ & $0(0 \%)$ & $0(0 \%)$ & 4.84 & 0.36 \\
\hline 2 & $\begin{array}{l}\text { The design of reservoirs is suitable to } \\
\text { prevent the mixing of drinking water } \\
\text { with other water in the case of multiple } \\
\text { types of water on cruise. }\end{array}$ & $\begin{array}{l}27 \\
(69.2 \%)\end{array}$ & $\begin{array}{l}11 \\
(28.2 \%)\end{array}$ & $\begin{array}{l}1 \\
(2.6 \%)\end{array}$ & $0(0 \%)$ & $0(0 \%)$ & 4.66 & 0.52 \\
\hline 3 & $\begin{array}{l}\text { Reservoirs are located in rooms that } \\
\text { preserve them. }\end{array}$ & $\begin{array}{l}24 \\
(61.5 \%)\end{array}$ & $\begin{array}{l}14 \\
(35.9 \%)\end{array}$ & $\begin{array}{l}1 \\
(2.6 \%)\end{array}$ & $0(0 \%)$ & $0(0 \%)$ & 4.58 & 0.54 \\
\hline
\end{tabular}




\begin{tabular}{|l|l|l|l|l|l|l|l|l|}
\hline 4 & $\begin{array}{l}\text { Drinking water tanks shall be made of } \\
\text { metal or other suitable material for the } \\
\text { storage of potable water and shall not } \\
\text { allow contamination. }\end{array}$ & $\begin{array}{l}23 \\
(59.0 \%)\end{array}$ & $\begin{array}{l}10 \\
(25.6 \%)\end{array}$ & $\begin{array}{l}3 \\
(7.7 \%)\end{array}$ & $\begin{array}{l}2 \\
(5.1 \%)\end{array}$ & $\begin{array}{l}1 \\
(2.6 \%)\end{array}$ & 4.33 & 1.01 \\
\hline 5 & $\begin{array}{l}\text { Regular maintenance of water tanks for } \\
\text { anti-corrosive coatings. }\end{array}$ & $\begin{array}{l}10 \\
(25.6 \%)\end{array}$ & $\begin{array}{l}28 \\
(71.8 \%)\end{array}$ & $\begin{array}{l}1 \\
(2.6 \%)\end{array}$ & $0(0 \%)$ & $0(0 \%)$ & 4.23 & 0.48 \\
\hline 6 & $\begin{array}{l}\text { The water tanks are equipped with a } \\
\text { ventilation outlet designed and designed } \\
\text { to prevent the entry of contaminated } \\
\text { materials and bacteria and protect it } \\
\text { with a well-sealed net that prevents the } \\
\text { entry of insects and contaminants. }\end{array}$ & $\begin{array}{l}27 \\
(69.2 \%)\end{array}$ & $\begin{array}{l}11 \\
(28.2 \%)\end{array}$ & $0(0 \%)$ & $\begin{array}{l}1 \\
(2.6 \%)\end{array}$ & $0(0 \%)$ & 4.64 & 0.62 \\
\hline 7 & $\begin{array}{l}\text { The tanks are regularly cleaned and } \\
\text { cleaned. }\end{array}$ & $\begin{array}{l}28 \\
(71.8 \%)\end{array}$ & $\begin{array}{l}10 \\
(25.6 \%)\end{array}$ & $\begin{array}{l}1 \\
(2.6 \%)\end{array}$ & $0(0 \%)$ & $0(0 \%)$ & 4.69 & 0.52 \\
\hline 8 & $\begin{array}{l}\text { No person with infectious disease is } \\
\text { allowed to enter the water tanks. }\end{array}$ & $\begin{array}{l}27 \\
(69.2 \%)\end{array}$ & $\begin{array}{l}11 \\
(28.2 \%)\end{array}$ & $0(0 \%)$ & $\begin{array}{l}1 \\
(2.6 \%)\end{array}$ & $0(0 \%)$ & 4.64 & 0.62 \\
\hline
\end{tabular}

\subsubsection{Mineral Water}

Table (10) illustrated that as regards mineral water; majority of study group more than $(90 \%)$ agreed on that frequently, and very frequently, in hotels that validation dates are confirmed on mineral water with a mean of (4.76), The specifications of the mineral water shall be ascertained and shall conform to the standard specifications with a mean of (4.66), water bottles are purchased from a reliable source of high quality with a mean of
(4.64), Ice cubes are made from mineral water bottles with a mean of (4.48), and The specifications for the quality of drinking water shall apply to both bottled water and ice prepared for human use with a mean of (4.84), with a general mean score above 4 . These results agreed with Arvanitoyannis et al. (2010), WHO (2017) and Manoiu and Craciun (2019).

Table 10

Mineral Water among Study Group.

\begin{tabular}{|l|l|l|l|l|l|l|l|l|}
\hline \multirow{2}{*}{ N. } & \multirow{2}{*}{ Element } & $\begin{array}{l}\text { Very } \\
\text { frequently }\end{array}$ & Frequently & $\begin{array}{l}\text { Not } \\
\text { sure }\end{array}$ & Scarcely & $\begin{array}{l}\text { Not too } \\
\text { frequent }\end{array}$ & Mean & S.D. \\
\cline { 3 - 7 } & No. (\%) & No. $(\%)$ & $\begin{array}{l}\text { No. } \\
(\%)\end{array}$ & No. (\%) & No. (\%) & \\
\hline 1 & $\begin{array}{l}\text { Validation dates are confirmed on } \\
\text { mineral water. }\end{array}$ & $\begin{array}{l}31 \\
(79.5 \%)\end{array}$ & $7(17.9 \%)$ & $\begin{array}{l}1 \\
(2.6 \%)\end{array}$ & $0(0 \%)$ & $0(0 \%)$ & 4.76 & 0.48 \\
\hline 2 & $\begin{array}{l}\text { The specifications of the mineral water } \\
\text { shall be ascertained and shall conform } \\
\text { to the standard specifications. }\end{array}$ & $\begin{array}{l}26 \\
(66.7 \%)\end{array}$ & $\begin{array}{l}13 \\
(33.3 \%)\end{array}$ & $0(0 \%)$ & $0(0 \%)$ & $0(0 \%)$ & 4.66 & 0.47 \\
\hline 3 & $\begin{array}{l}\text { Water bottles are purchased from a } \\
\text { reliable source of high quality. }\end{array}$ & $\begin{array}{l}25 \\
(64.1 \%)\end{array}$ & $\begin{array}{l}14 \\
(35.9 \%)\end{array}$ & $0(0 \%)$ & $0(0 \%)$ & $0(0 \%)$ & 4.64 & 0.48 \\
\hline 4 & $\begin{array}{l}\text { Ice cubes are made from mineral water } \\
\text { bottles. }\end{array}$ & $\begin{array}{l}19 \\
(48.7 \%)\end{array}$ & $\begin{array}{l}20 \\
(51.3 \%)\end{array}$ & $0(0 \%)$ & $0(0 \%)$ & $0(0 \%)$ & 4.48 & 0.50 \\
\hline 5 & $\begin{array}{l}\text { The specifications for the quality of } \\
\text { drinking water shall apply to both } \\
\text { bottled water and ice prepared for } \\
\text { human use. }\end{array}$ & $33(84.6 \%)$ & $6(51.4 \%)$ & $0(0 \%)$ & $0(0 \%)$ & $0(0 \%)$ & 4.84 & 0.36 \\
\hline
\end{tabular}

\section{Conclusions and Discussions}

Application of the water safety plan to ship water systems, including potable water, recreational water facilities and decorative water features, is expected to improve water management on ships.
The success of a water safety evaluation depends on support from senior management, commitment of the Captain and crew members, and correct execution of all steps of a risk assessment and practicality and applicability in routine operation. Through the results, it can be seen that the study 
showed by analyzing a sample of water on floating hotels, where it was found that the water is suitable for human consumption and that it is safe to drink and there are no concerns, problems or damages from its use by workers on the ship or tourists coming. The study showed that as regards internal use of water; $(79.5 \%)$ and $(71.8 \%)$ were very frequently obtain water from external sources and stored and obtain it through Nile water and is analyzed and processed; respectively with mean score above 4 . The results confirmed that the organization of water supply to and on ships differs considerably from that of water supply on ground. The results also confirmed that risks of contamination can arise from source water at the port or during loading, storage, or distribution on the cruise. Where the results confirmed that water hygiene and food safety are inextricably linked. More than $(80 \%)$ of study group mentioned that frequently, and very frequently, there is a water management plan on cruise with a mean of (4.66), The quality of water on board is confirmed by specialists with a mean of (4.52), High-quality water management arrangements are in place to prepare food and beverages, The quantities of water suitable for human use on board are adequately supplied to meet the projected needs for all purposes, with a general mean score above 4 . As regards water treatment more than $85 \%$, a Proper cleaning materials are provided, Pre-used water is used again after treatment in other uses, The proportion of disinfectants shall be determined to provide the lowest level of safety according to the permissible rates, The chemicals used in such treatment are subject to safety and safety procedures, Taste and flavor are lacking due to processing and may be unappealing to all, Water is disinfected and chemicals are added in appropriate quantities in accordance with the required specifications and tolerances, and the processing units are designed to ensure efficient operation with the production of potable water in accordance with international quality; with a general mean score above 4 . More than $85 \%$ of study group agreed on that frequently, and very frequently, in hotels that Chemical and microbiological analyzes are carried out to measure water quality continuously, Ships are provided with water that complies with World Health Organization (WHO) guidelines on the quality of water suitable for human use, Precautions are taken to prevent water contamination and a strategy for the prevention of waterborne diseases is followed; with a general mean above 4 . More than $85 \%$ of study group agreed on that frequently, and very frequently, in hotels that the Maintenance, cleaning and periodic maintenance of water tanks with a mean of (4.84), The design of reservoirs is suitable to prevent the mixing of drinking water with other water in the case of multiple types of water on cruise with a mean of 4.66 .

\section{Recommendations}

It is essential to detect routinely water quality on board cruises. This monitoring should be performed taking into account element and microbiological parameters, with the objective of identifying possible contamination sources and early changes of the hygienic characteristics of water. It is eligible that these activities are performed by a designed crew member, using specific kits. More detailed assessments should be under the tasks of specialized personnel at least double year. Specific analyses should involve specimen collected from all tanks and sites of water distribution. It is important that at least one crew member is trained to know and understand proper water handling procedures in loading and know how to disinfect water. This will help in monitoring handling of the cruise water system. Appropriate training program and the publication of a manual of perfect practices for water handling on board merchant cruise should be followed and prepared by organizations with acknowledged experience in the field.

The following recommendations are therefore made, resulting from this research:

\subsection{Recommendations for Floating Hotels' Staff}

1- Staff must keep food, water and materials on board of the cruise as safe as possible.

2- Staff should be well trained in cruise sanitation and have all the equipment, facilities, materials and capacity necessary to permit the maintenance of a sanitary environment on board.

3- Cruises' staff should be familiar with the floating hotel's procedures for resolving problems with the fresh water supply as soon as possible.

\subsection{Recommendations for Management and Heads Department of Floating Hotels}

1- Water safety plans should be recognized to ensure the safety of a water supply on cruises.

2- A proper yearly training plan should be sophisticated and followed and staff should be provided with continuous training to improve their 
service efficiency and preparation of capacity development.

3- Increased awareness and understanding of the pollution characteristics of the water system on cruises.

4- The design and construction of the ship should be as failsafe as possible with respect to maintaining a sanitary environment.

5- A risk management system must be recognized and maintained to ensure that public health risks are identified, reported and mitigated in the event of any problems, pollutants or damage to water quality in cruises.

6- Potable water must be provided in appropriate quantity and quality to avoid immediate or longterm harms on board of the cruises.

\subsection{Recommendations Addressed to Officials and Observers}

1- The regulatory authorities in the country must take into account the recommendations that are looking to develop an integrated program for water quality management in cruises.

2- The law must be effectively implemented in the event of any contravention, especially water quality and pollution in floating hotels.

3- Constant monitoring of the Nile River water quality is needed to record any alteration in the quality and mitigate outbreak of health trouble and the detrimental impacts on the aquatic ecosystem.

4- The responsible authorities should take all basic preventive measures as it must be verified that the water loaded on board the vessel complies with the standards of the World Health Organization (WHO) and Guidelines for Drinking Water Quality (GDWQ) or the relevant national standards if they are more stringent.

5- Asking the responsible authorities to conduct workshops and periodic studies on the microbiological and chemical relationship pollution to human health and to benefit from these results.

\section{References}

Aijuka, M. \& Buys, E. (2013). Irrigation Water as a Source of Antibiotic Resistant \& Virulent coli on Lettuce. International Association for Food Protection (IAFP) Conference, Charlotte Convention Centre, USA, 28-31.

Allam, G. (2007). International Water Resources Association. Water International, Water Resources in Egypt, 32(2), 205- 218.
Amenta, F., Carotenuto, A. \& Grappasonni, I. (2011). Healthy Ship: An Innovative Project for Health Care Improvement \& Health Promotion on Board Ships. Med-e-Tel Proceedings of the International Health, Telemedicine \& Health ICT Forum for Education, Networking \& Business. Luxembourg, 6(8), 708-711.

American Public Health Association (APHA) (2017). Standard Methods for the Examination of Water and Wastewater. $23^{\text {rd }}$ ed., Washington, DC.

American Society of Sanitary Engineering (ASSE) (2016). Chemical Dispensing Systems. Westlake, $\mathrm{OH}$.

American Water Works Association (AWWA) (2006). Water Chlorination \& Chlorination Principles \& Practices, 2nd edition. Denver, CO.

American Water Works Association (AWWA) (2015). Recommended Practice for Backflow Prevention \& Cross-Connection Control. 4th edition. Denver, CO.

American Water Works Association (AWWA) (2016). Simplified Procedures for Water Examination. $6^{\text {th }}$ edition. Denver, CO.

Andriotis, K., \& Agiomirgianakis, G. (2010). Cruise Visitor's Experience in a Mediterranean Port of Call. International Journal of Tourism Research, 12(3), 390-404.

Arvanitoyannis, I., Hadjichristodoulou, C., Tserkezou, P., Mouchtouri, V., Kremastinou, J. \& Nichols, G. (2010). EU Legislation on Food and Potable Water Safety which could be Potentially Applied on Board Ferries \& Cruise Ships: A Comparison with US Legislation. Critical Rev Food Science Nutrition, 50(2), 533-566.

Bartram, J., Corrales, L., Davison, A., Deere, D., Drury, D., Gordon, B., Howard, G., Rinehold, A. \& Stevens, M. (2009). Water Safety Plan Manual: Step-by-Step Risk Management for DrinkingWater Suppliers. World Health Organization, Geneva, 75-88.

Brida, J. \& Zapata, A. (2010). Cruise Tourism:

Economic, Socio-Cultural \& Environmental Impacts. International Journal of Leisure \& Tourism Marketing, 1(3), 205-226.

Brotherton, J., Delpech, V., Gilbert, G., Hatzi, S., Paraskevopoulos, P. \& Mcanulty, J. (2003). A Large Outbreak of Influenza A and B on a Cruise Ship Causing Widespread Morbidity. Epidemiology \& Infection, 130(2), 263-271.

Davison, A., Howard, G., Stevens, M., Callan, P., Fewtrell, L., Deere, D. \& Bartram, J. (2005). Water Safety Plans: Managing Drinking-Water Quality from Catchment to Consumer. World Health Organization, Geneva, (document WHO/SDE/WSH/05.06).

Du Plessis, E., Duvenage, F. \& Korsten, L. (2015). Determining the Potential Link between Irrigation Water Quality \& the Microbiological Quality of 
Onions by Phenotypic \& Genotypic Characterization of Escherichia Coli Isolates. Journal of Food Protection, 78(2), 643-651.

Egypt Tour Plus (ETP) (2019). Nile Cruises from Luxor to Aswan. https://www.egypttoursplus.com/nilecruises-from-luxor-to-aswan/.

Egyptian Ministry of Tourism (EMT) (2020). Tourism: Occupancy Rate of Floating Hotels in Luxor and Aswan. Report.

Gaber, H., El-Kasheif, M., Ibrahim, S. \& Authman, M. (2013). Effect of Water Pollution in El-Rahawy Drainage Canal on Hematology \& Organs of Freshwater Fish. World Applied Sciences Journal, 21(3), 329-341.

Grenfell, P., Little, C. \& Surman-Lee, S. (2008). The Microbiological Quality of Potable Water on Board Ships Docking in the UK \& the Channel Islands: an Association of Port Health Authorities \& Health Protection Agency Study. Water Health, 6(2), 215224.

Hamed, M., Mohamedein, L., El-Sawy, M. \& ElMoselhy, K. (2013). Mercury and Tin Contents in Water \& Sediments along the Mediterranean Shoreline of Egypt. The Egyptian Journal of Aquatic Research, 39(2), 75-81.

Han, J., Xu, Z., Xing, H., Tan, J., Wang, M., Zhang, X., Kong, F., Si, J., Li, X., Tang, L. \& Tian, P. (2007). Influence of Water Supply Improvement on Incidence and Mortality of Esophageal Cancer in Linzhou, Henan Journal of Preventive Medicine, 16, 79-80.

Health Protection Agency (HPA) (2003). The Guidelines for Water Quality on Board Merchant Ships including Passenger Vessels. London.

Ibrahim, S. (2013). Effect of Water Quality Changes on Gills \& Kidney Histology of Oreochromis niloticus Fish Inhabiting the Water of Rosetta Branch. River Nile, Egypt. World Applied Sciences Journal, 26(4), 438-448.

Iolanda, G., Mario, C., Rolando, D., Andrea, S., Fabio, S., Stefania, S. \& Francesco, A. (2013). Recommendations for assessing water quality and safety on board merchant ships. Int Marit Health, Rome, Italy, 64 (3), 154-159.

ISO (2006). Standard ISO 5667-1: Water QualitySampling-Part 1: Guidance on the Design of Sampling Programs \& Sampling Techniques. Geneva, International Organization for Standardization.

ISO (2007). Standard ISO 10703: Water QualityDetermination of the Activity Concentration of Radionuclides-Method by High Resolution Gamma-ray Spectrometry. Geneva, International Organization for Standardization.

Lasserre F. \& Tetu P. (2015). The Cruise Tourism Industry in the Canadian Arctic: Analysis of Activities \& Perceptions of Cruise Ship Operators. Polar Record, 51(1), 24-38.
Liang, S., Cao, Y., Kohei, A., Chen, Z., Huang, S., Song, G., Li, H. \& Wang, S. (2012). Study on Levels of Nitrate Nitrogen, Nitrite Introgen and Ammonia in Drinking Water in the High-Incidence Area of Esophageal Cancer. Chinese Journal of Cancer Prevention and Treatment, 19(4), 649-651.

Manoiu, V. \& Craciun, A. (2019). Water Management on Board Disney Cruise Line Company Ships: Methods and Legislation. Air and Water Components of the Environment Conference Proceedings, Cluj-Napoca, Romania, p. 345-356.

Marı'a, J., Gunnarsdo, T. \& Loftur, R. (2008). HACCP \& Water Safety Plans in Icelandic Water Supply: Preliminary Evaluation of Experience. Journal of Water and Health, Sudurlandsbraut, Reykjavi'k, Iceland, 108, 1-7.

Meyer, G., Neubauer, B. \& Schepers, B. (2007). Contamination of Tap Water on Oceanic Going Vessel. Into J. Environmental Health, 17, 157-159.

Miller, R., Guice, J. \& Deere, D. (2009). Risk Assessment for Drinking Water Sources, Research Report No 78. Water Quality Research Australia Limited, Adelaide.

Mouchtouri, V., Bartlett, C., Diskin, A. \& Hadjichristodoulou, C. (2012). Water Safety Plan on Cruise Ships: A promising Tool to Prevent Waterborne Diseases. Science Total Environment, 429(2), 199-205.

Murray, T. \& Taylor, M. (2015). Quantification \& Molecular Characterization of Human Sap Viruses in Water Sources Impacted by Highly-Polluted Discharged Wastewater in South Africa. Journal of Water and Health.

NSF International (2013). Drinking Water System Components-Health Effects. ANSI/NSF Standard 61, Ann Arbor, MI.

NSF International (2016). Water Heaters, Hot Water Supply Boilers \& Heat Recovery Equipment. NSF 5, Ann Arbor, MI.

Ormeci, B., Ishida, G. \& Linden, K. (2005). UV Disinfection of Chlorinated Water: Impact on Chlorine Concentration \& UV dose Delivery. Water Suppl Res Technol, 54(3), 189-99.

Schlaich, C., Oldenburg, M. \& Lamshöft, M. (2009). Estimating the Risk of Communicable Diseases Aboard Cargo Ships. J Travel Med, 16(4), 402- 406.

Soller, J., Schoen, M., Bartrand, T., Ravenscroft, J. \& Ashbolt, N. (2010). Estimated Human Health Risks from Exposure to Recreational Waters Impacted by Human \& Non-Human Sources of Faucal Contamination. Water Research, 44(2), 4674-91.

Srećko, K. (2016). Fresh Water Supply from Different Sources in the Shipping. International Conference on Manufacturing Engineering \& Materials, ICMEM, Nový Smokovec, Slovakia, 149, 190-196.

Taylor, E. (2008). HACCP for the Hospitality Industry: History in the Making. International Journal of 
Contemporary Hospitality Management, 20(5), 480-493.

Toufeek, M. (2011). Distribution of Cadmium \& Lead in Aswan Reservoir \& River Nile Water at Aswan. World Applied Sciences Journal, 13(2), 369-375.

Ufermann, P., Petersen, H. \& Exner, M. (2011). Disinfection Aboard Cruise Liners \& Naval Units: Formation of Disinfection by Products Using Chlorine Dioxide in Different Qualities of Drinking Water. Int J Hyg Environ Health, 215, 86-90.

Wahab, R. \& Badawy, M. (2004). Water Quality Assessment of the River Nile System: An

Other Supporting Information, Geneva, Switzerland.

World Health Organization (WHO) (2011). Guide to Ship Sanitation. 3rd Ed. WHO.

World Health Organization (WHO) (2017). Guidelines for Drinking-Water Quality. 4th edition, Geneva, Switzerland, 1.

World Health Organization (WHO) (2009). Guide to Hygiene \& Sanitation in Aviation, Water; Cleaning \& Disinfection of Facilities. Geneva, World Health Organization,

http://www.who.int/water_sanitation_health/hygie ne/ships/guide_hygiene_sanitation_aviation_3_edi tion.pdf, accessed 30 January 2011.

World Health Organization (WHO) (2010). International Health Regulations. Recommended Procedures for Inspection of Ships \& Issuance of Ship Sanitation Certificates. Draft document. Geneva, World Health Organization, http://www.who.int/ihr/ports_airports/ssc_ guide_draft_27_may_2010.pdf, accessed 30 January 2011.

Zhou, Y., Xiao, J., Ying, M., Chen, Z., Chen, B. \& Chen, H. (2009). Investigation on the Quantity of Chemical Elements, Nitrate in the Drinking Water in the High and Low Gastric Cancer Incidence Area. Chinese Journal of Disease Control \& Prevention, China, 13(4), 619-620.
Overview. Biomedical and Environmental Sciences, 17(2), 87-100.

Wang, Y., Tang, K., Xu, Z., Tang, Y. \& Liu, H. (2009). Water Quality Assessment of Surface Drinking Water Sources in Cities and Towns of China. Water Resources Protection, 25, 1-4.

Wendy, G. (2019). Everything you Need to Know about Cruising the Nile. Travel Writer, https://www.telegraph.co.uk/travel/cruises/articles/ nile-cruise-guide/

World Health Organization (WHO) (2002). Guidelines for Drinking-Water Quality. Health Criteria \& 